\title{
Novel Cathode Materials for Sodium Ion Batteries Derived from Layer Structured Titanate $\mathrm{Cs}_{2} \mathrm{Ti}_{5} \mathrm{O}_{11} \cdot(1+\mathrm{x}) \mathrm{H}_{2} \mathrm{O}$
}

\author{
Masao Ohashi \\ Tokuyama College of Technology, Gakuendai, Shunan City, Japan \\ Email:oohasi@tokuyama.ac.jp
}

How to cite this paper: Ohashi, M. (2018) Novel Cathode Materials for Sodium Ion Batteries Derived from Layer Structured Titanate $\mathrm{Cs}_{2} \mathrm{Ti}_{5} \mathrm{O}_{11} \cdot(1+\mathrm{x}) \mathrm{H}_{2} \mathrm{O}$. Materials Sciences and Applications, 9, 526-533. https://doi.org/10.4236/msa.2018.96037

Received: March 29, 2018

Accepted: May 25, 2018

Published: May 28, 2018

Copyright $\odot 2018$ by author and Scientific Research Publishing Inc. This work is licensed under the Creative Commons Attribution International License (CC BY 4.0).

http://creativecommons.org/licenses/by/4.0/

\section{(c) (i) Open Access}

\begin{abstract}
A layer structured titanate $\mathrm{Cs}_{2} \mathrm{Ti}_{5} \mathrm{O}_{11} \cdot(1+\mathrm{x}) \mathrm{H}_{2} \mathrm{O}(\mathrm{x}=0.70)$ has been prepared in a solid state reaction using $\mathrm{Cs}_{2} \mathrm{CO}_{3}$ and anatase type $\mathrm{TiO}_{2}$ at $900^{\circ} \mathrm{C}$. Ion exchange reactions of $\mathrm{Cs}^{+}$in the interlayer space were studied in aqueous solutions. The single phases of $\mathrm{Li}^{+}, \mathrm{Na}^{+}$and $\mathrm{H}^{+}$exchange products were obtained. The three kinds of resulting titanates were evaluated for use as the cathodes in rechargeable sodium batteries after dehydrations by heating at $200^{\circ} \mathrm{C}$ in a vacuum. The electrochemical measurements showed that they exhibited the reversible $\mathrm{Na}^{+}$intercalation-deintercalation in a voltage range of $0.5-3.5 \mathrm{~V}$ or $0.7-4.0 \mathrm{~V}$. The $\mathrm{Li}^{+}$exchange product showed the best performance of the discharge-charge capacities in this study. The initial $\mathrm{Na}^{+}$intercalation-deintercalation capacities of the $\mathrm{Li}_{2} \mathrm{Ti}_{5} \mathrm{O}_{11}$ were $120 \mathrm{mAh} / \mathrm{g}$ and 100 $\mathrm{mAh} / \mathrm{g}$; the amounts of $\mathrm{Na}^{+}$correspond to 1.9 and 1.6 of the formula unit, respectively. The titanates are nontoxic, inexpensive and environmentally benign.
\end{abstract}

\section{Keywords}

Cathode Material, Sodium Ion Battery, Layer Structured Titanate, Environmentally Benign

\section{Introduction}

Sodium ion batteries have emerged for the ideal alternative to the lithium ion batteries which have the problems of lithium availability and cost. We have studied the characterizations of layer structured titanates and Niobate [1]-[8] for the cathodes of lithium ion batteries. In a previous study [8], we showed that $\mathrm{Cs}_{0.67} \mathrm{Li}_{3.01} \mathrm{H}_{0.73} \mathrm{Nb}_{6} \mathrm{O}_{17}$ derived by ion exchange reaction from layer structured Niobate $\mathrm{Cs}_{4} \mathrm{Nb}_{6} \mathrm{O}_{17}$ exhibited rechargeable capacity of more than $110 \mathrm{mAh} / \mathrm{g}$ in 
the lithium battery in the voltage range of $1.5-4.2 \mathrm{~V}$. The discharge-charge capacity corresponds to a redox reaction of $\mathrm{Nb}^{5+} / \mathrm{Nb}^{4+}$ in the layered niobate with the intercalation-deintercalation of $\mathrm{Li}^{+}$. In the present study, we found that novel cathode materials for sodiumion batteries derived by ion exchange reactions from a layered titanate of $\mathrm{Cs}_{2} \mathrm{Ti}_{5} \mathrm{O}_{11} \cdot(1+\mathrm{x}) \mathrm{H}_{2} \mathrm{O}$.

The crystal structure of $\mathrm{Cs}_{2} \mathrm{Ti}_{5} \mathrm{O}_{11}$ is shown in Figure 1 [9]. Each stacking layer consists of corrugated layer of titanium-oxygen. Ordinary $\mathrm{TiO}_{6}$ octahedra are continuous in two dimensions. The framework is built up by five $\mathrm{TiO}_{6}$ octahedra sharing edges. These unites are joined to the same block sharing edges to form zig-zag layers and sharing corners staggered sheets forming $\left[\mathrm{Ti}_{5} \mathrm{O}_{11}\right]^{2-}$ layers. The charge balance is maintained by interlayer $\mathrm{Cs}^{+}$ions which are eight-coordinated by oxygen atoms of the adjacent layers. The titanate $\mathrm{Cs}_{2} \mathrm{Ti}_{5} \mathrm{O}_{11}$ intends to contain water molecules in the interlayer space with $\mathrm{Cs}^{+}$from the air at room temperature forming $\mathrm{Cs}_{2} \mathrm{Ti}_{5} \mathrm{O}_{11} \cdot(1+\mathrm{x}) \mathrm{H}_{2} \mathrm{O}(0.5<\mathrm{x}<1)$.

\section{Experimental}

The layer structured titanate $\mathrm{Cs}_{2} \mathrm{Ti}_{5} \mathrm{O}_{11} \cdot(1+\mathrm{x}) \mathrm{H}_{2} \mathrm{O}$ has been prepared in a solid state reaction using $\mathrm{Cs}_{2} \mathrm{CO}_{3}$, anatase type $\mathrm{TiO}_{2}$ at $900^{\circ} \mathrm{C}$ according to a similar method reported by Grey et al. [10]. The mixture with the desired ratio was heated for $20 \mathrm{~h}$ and the resulting powder was ground and heated again at $900^{\circ} \mathrm{C}$

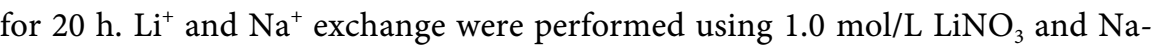
$\mathrm{NO}_{3}$ solutions for 9 days at $60^{\circ} \mathrm{C}$ The solutions were changed every 3 days. The $\mathrm{H}^{+}$exchange was carried out using $0.05 \mathrm{~mol} / \mathrm{L} \mathrm{H}_{2} \mathrm{SO}_{4}$ solution for 3 days at room temperature, changing the solution every day.

Powder X-ray diffraction (XRD) patterns were collected by a Rigaku Ultima IV diffractometer over $2 \theta$ range of $10^{\circ}$ to $70^{\circ}$ using graphite monochromatized $\mathrm{CuK}_{\alpha}$ radiation $(\lambda=0.15405 \mathrm{~nm})$. The contents of $\mathrm{Cs}, \mathrm{Li}$ and $\mathrm{Na}$ in the samples were determined by the atomic absorption method after dissolving the samples in a mixed acid solution with $\mathrm{H}_{2} \mathrm{SO}_{4}$ and HF. Dehydration processes were studied by TG-DTA at a heating rate of $10^{\circ} \mathrm{C} / \mathrm{min}$. A cathode was formed of a

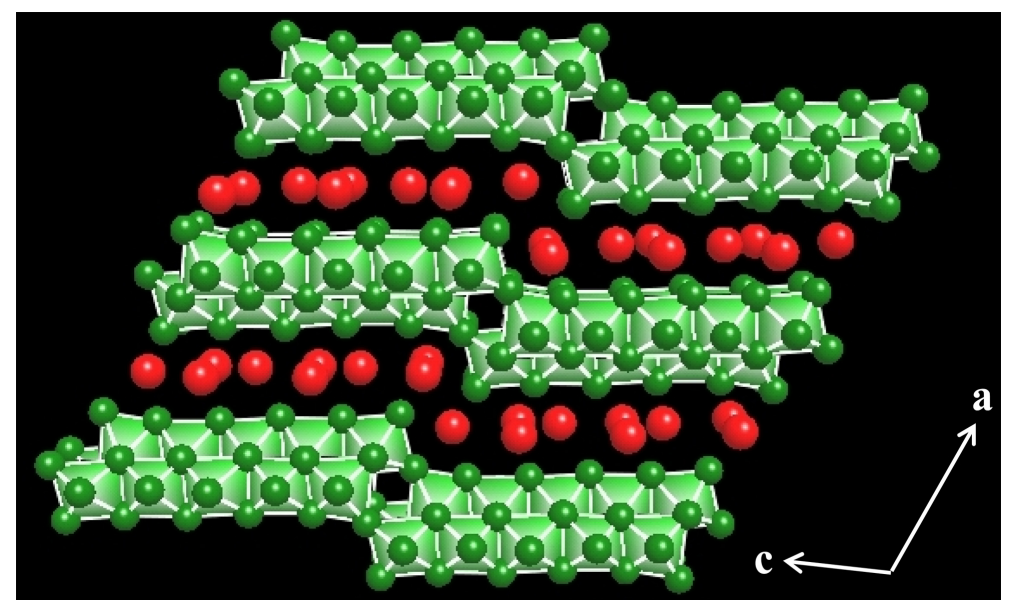

Figure 1. Crystal structure of $\mathrm{Cs}_{2} \mathrm{Ti}_{5} \mathrm{O}_{11}$ seen from the direction of the $\mathrm{b}$ axis. 
mixture of the titanate powder (80 wt\%), acetylene black (10 wt\%) and PTFE binder (10 wt $\%)$ pressed into a stainless steel grid under a pressure of $100 \mathrm{MPa}$. The electrolyte of the sodium cell was $1.0 \mathrm{~mol} / \mathrm{L} \mathrm{NaClO}_{4}$ solution of propylene carbonate (PC) and an anode was sodium metal. The cells were first discharge and cycled between $0.5 \mathrm{~V}$ and $3.5 \mathrm{~V}$ or $0.7 \mathrm{~V}$ and $4.0 \mathrm{~V}$ at $0.10 \mathrm{~mA} / \mathrm{cm}^{2}$ in an argon-filled glove box at room temperature.

\section{Result and Discussion}

\subsection{Preparation of $\mathrm{Cs}_{2} \mathrm{Ti}_{5} \mathrm{O}_{11} \cdot(1+\mathrm{x}) \mathrm{H}_{2} \mathrm{O}$}

The XRD pattern of $\mathrm{Cs}_{2} \mathrm{Ti}_{5} \mathrm{O}_{11} \cdot(1+\mathrm{x}) \mathrm{H}_{2} \mathrm{O}$ (Figure 2(a)) was indexed on the basis of a monoclinic cell of $\mathrm{a}=2.470(3) \mathrm{nm}, \mathrm{b}=0.3785(4) \mathrm{nm}, \mathrm{c}=1.573(2) \mathrm{nm}$ and $\beta=123.7(1)^{\circ}$ (Table 1 ). The lattice constants of the sample are consistent with those prepared by Reid et al. $(\mathrm{a}=2.3849(8) \mathrm{nm}, \mathrm{b}=0.3800(1) \mathrm{nm}, \mathrm{c}=1.4918(6)$ $\mathrm{nm}$ and $\beta=121.27(3)^{\circ}$ ) [10]. The TGA curve of the compound (Figure 3(a)) shows a weight loss from $20^{\circ} \mathrm{C}$ to $200^{\circ} \mathrm{C}$; this corresponds to the dehydration of the interlayer water. The composition was estimated to be $\mathrm{Cs}_{2} \mathrm{~T}_{5} \mathrm{O}_{11} \cdot 1.7 \mathrm{H}_{2} \mathrm{O}(\mathrm{x}=$ 0.7 in $\left.\mathrm{Cs}_{2} \mathrm{Ti}_{5} \mathrm{O}_{11} \cdot(1+\mathrm{x}) \mathrm{H}_{2} \mathrm{O}\right)$ from the weight loss.

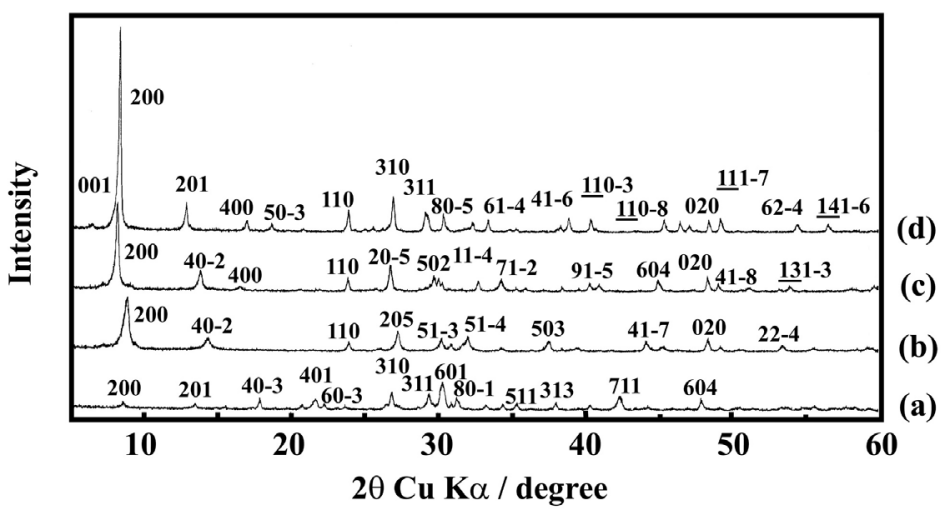

Figure 2. XRD patterns of (a) $\mathrm{Cs}_{2} \mathrm{~T}_{5} \mathrm{O}_{11} \cdot 1.7 \mathrm{H}_{2} \mathrm{O}$, (b) $\mathrm{Li}_{2} \mathrm{Ti}_{5} \mathrm{O}_{11} \cdot 3.6 \mathrm{H}_{2} \mathrm{O}$, (c) $\mathrm{Na}_{2} \mathrm{~T}_{5} \mathrm{O}_{11} \cdot 4 \cdot 1 \mathrm{H}_{2} \mathrm{O}$ and (d) $\mathrm{H}_{2} \mathrm{~T}_{5} \mathrm{O}_{11} \cdot 3.3 \mathrm{H}_{2} \mathrm{O}$.

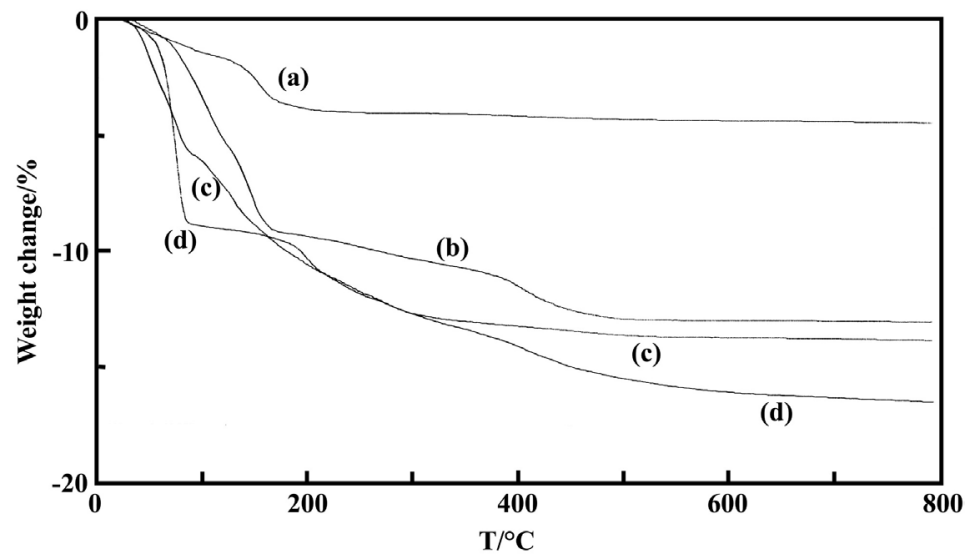

Figure 3. TGA curves of (a) $\mathrm{Cs}_{2} \mathrm{~T}_{5} \mathrm{O}_{11} \cdot 1.7 \mathrm{H}_{2} \mathrm{O}$, (b) $\mathrm{Li}_{2} \mathrm{Ti}_{5} \mathrm{O}_{11} \cdot 3.6 \mathrm{H}_{2} \mathrm{O}$, (c) $\mathrm{Na}_{2} \mathrm{~T}_{5} \mathrm{O}_{11} \cdot 4.1 \mathrm{H}_{2} \mathrm{O}$ and (d) $\mathrm{H}_{2} \mathrm{~T}_{5} \mathrm{O}_{11} \cdot 3 \cdot 3 \mathrm{H}_{2} \mathrm{O}$. 
Table 1. Compositions and monoclinic lattice constants of the products.

\begin{tabular}{ccccc}
\hline Compositions & $\mathrm{a} / \mathrm{nm}$ & $\mathrm{b} / \mathrm{nm}$ & $\mathrm{c} / \mathrm{nm}$ & $\beta /^{\circ}$ \\
\hline $\mathrm{Cs}_{2} \mathrm{Ti}_{5} \mathrm{O}_{11} \cdot 1.7 \mathrm{H}_{2} \mathrm{O}$ & $2.470(3)$ & $0.3785(4)$ & $1.573(2)$ & $123.7(1)$ \\
$\mathrm{Li}_{2} \mathrm{Ti}_{5} \mathrm{O}_{11} \cdot 3.6 \mathrm{H}_{2} \mathrm{O}$ & 2.48 & 0.376 & 1.76 & 127 \\
$\mathrm{Na}_{2} \mathrm{Ti}_{5} \mathrm{O}_{11} \cdot 4.1 \mathrm{H}_{2} \mathrm{O}$ & 2.58 & 0.375 & 1.77 & 125 \\
$\mathrm{H}_{2} \mathrm{Ti}_{5} \mathrm{O}_{11} \cdot 3.3 \mathrm{H}_{2} \mathrm{O}$ & 2.53 & 0.375 & 1.76 & 125 \\
\hline
\end{tabular}

\subsection{Ion Exchange}

The XRD pattern of the $\mathrm{Li}^{+}$exchange product is shown in Figure 2(b). The pattern was indexed as a single phase with monoclinic lattice constants of $\mathrm{a}=2.48$ $\mathrm{nm}, \mathrm{b}=0.376 \mathrm{~nm} \mathrm{c}=1.76 \mathrm{~nm}$ and $\beta=127^{\circ}$ (Table 1). These lattice constants of $\mathrm{a}$ and $\mathrm{b}$ were almost unchanged. This show that the host layer of $\mathrm{Cs}_{2} \mathrm{Ti}_{5} \mathrm{O}_{11} \cdot(1+$ $\mathrm{x}) \mathrm{H}_{2} \mathrm{O}$ is maintained through the $\mathrm{Li}^{+}$exchange. The TGA curve (Figure $3(\mathrm{~b})$ ) shows two steps of weight loss: $25^{\circ} \mathrm{C}-170^{\circ} \mathrm{C}$ and $170^{\circ} \mathrm{C}-450^{\circ} \mathrm{C}$. The both steps correspond to the dehydration of the interlayer water. $\mathrm{Cs}$ analysis indicated that more than $99.9 \%$ of the interlayer $\mathrm{Cs}^{+}$was ion exchanged with $\mathrm{Li}^{+}$. The composition was estimated to be $\mathrm{Li}_{2} \mathrm{Ti}_{5} \mathrm{O}_{11} \cdot 3 \cdot 6 \mathrm{H}_{2} \mathrm{O}$ at room temperature and $\mathrm{Li}_{2} \mathrm{Ti}_{5} \mathrm{O}_{11} \cdot 1.0 \mathrm{H}_{2} \mathrm{O}$ at $170^{\circ} \mathrm{C}$.

The XRD pattern of the $\mathrm{Na}^{+}$exchange product is shown in Figure 2(c). The pattern was indexed as a single phase with monoclinic lattice constants of $\mathrm{a}=$ $0.258 \mathrm{~nm}, \mathrm{~b}=0.375 \mathrm{~nm} \mathrm{c}=1.77 \mathrm{~nm}$ and $\beta=125^{\circ}$ (Table 1 ). This show that the host layer of $\mathrm{Cs}_{2} \mathrm{Ti}_{5} \mathrm{O}_{11} \cdot(1+\mathrm{x}) \mathrm{H}_{2} \mathrm{O}$ is also maintained through the $\mathrm{Na}^{+}$exchange. The TGA curve of the product (Figure $3(\mathrm{a})$ ) shows a gradual weight loss from $20^{\circ} \mathrm{C}$ to $600^{\circ} \mathrm{C}$; this corresponds to the dehydration of the interlayer water. Cs analysis indicated that more than $99.8 \%$ of the interlayer $\mathrm{Cs}^{+}$was ion exchanged with $\mathrm{Na}^{+}$. The composition was estimated to be $\mathrm{Na}_{2} \mathrm{~T}_{5} \mathrm{O}_{11} \cdot 4 \cdot 1 \mathrm{H}_{2} \mathrm{O}$ by chemical analysis and the weight loss.

The XRD pattern of the $\mathrm{H}^{+}$exchange product is shown in Figure 2(d). The pattern was indexed as a single phase with monoclinic lattice constants of $\mathrm{a}=$ $0.253 \mathrm{~nm}, \mathrm{~b}=0.375 \mathrm{~nm} \mathrm{c}=1.76 \mathrm{~nm}$ and $\beta=125^{\circ}$ (Table 1). This also shows that the host layer of $\mathrm{Cs}_{2} \mathrm{Ti}_{5} \mathrm{O}_{11} \cdot(1+\mathrm{x}) \mathrm{H}_{2} \mathrm{O}$ is maintained through the $\mathrm{H}^{+}$exchange. The TGA curve (Figure $3(\mathrm{~d})$ ) shows two steps of weight loss: $30^{\circ} \mathrm{C}-80^{\circ} \mathrm{C}$ and $150^{\circ} \mathrm{C}-500^{\circ} \mathrm{C}$. The former weight loss corresponds to the dehydration of the interlayer water and the latter corresponds to the mixture of dehydration of the interlayer water and decomposition caused by the combination of the exchanged $\mathrm{H}^{+}$with $\mathrm{O}^{2-}$ of the host layer. Cs analysis indicated that more than $99.6 \%$ of the interlayer $\mathrm{Cs}^{+}$was ion exchanged with $\mathrm{H}^{+}$. The compositions were estimated to be $\mathrm{H}_{2} \mathrm{Ti}_{5} \mathrm{O}_{11} \cdot 3.3 \mathrm{H}_{2} \mathrm{O}$ at room temperature and $\mathrm{H}_{2} \mathrm{Ti}_{5} \mathrm{O}_{11} \cdot 1 \cdot 0 \mathrm{H}_{2} \mathrm{O}$ at $80^{\circ} \mathrm{C}$. Sasaki et al. [11] reported the formations of $\mathrm{H}^{+}$exchange product of $\mathrm{H}_{2} \mathrm{Ti}_{5} \mathrm{O}_{11} \cdot 3 \mathrm{H}_{2} \mathrm{O}$ (air-dried) and $\mathrm{H}_{2} \mathrm{Ti}_{5} \mathrm{O}_{11} \cdot 1.0 \mathrm{H}_{2} \mathrm{O}$ (heated at $100^{\circ} \mathrm{C}$ ) using $1 \mathrm{M} \mathrm{HCl}$ solution. The compositions of the $\mathrm{H}^{+}$exchange products obtained in this study are consistent with those reported by them. 


\subsection{Sodium Battery}

The $\mathrm{Li}^{+}, \mathrm{Na}^{+}$and $\mathrm{H}^{+}$exchange products were evaluated for use as the cathodes in rechargeable sodium batteries after dehydrations by heating at $200^{\circ} \mathrm{C}$ for 1 hour in a vacuum.

Figure 4 shows the discharge-charge curves of $\mathrm{Na} / \mathrm{Li}_{2} \mathrm{Ti}_{5} \mathrm{O}_{11}$ cell. The cell voltage decreased from $2.7 \mathrm{~V}$ to $1.2 \mathrm{~V}$ and then decreased slowly to the cutoff voltage of $0.7 \mathrm{~V}$. The discharge capacity was $120 \mathrm{mAh} / \mathrm{g}$ for the first cycle. The amount of $\mathrm{Na}^{+}$intercalated in this process was 1.9 for the formula unit. The discharge potential of $\mathrm{Ti}^{4+} / \mathrm{Ti}^{3+}$ in a titanate of $\mathrm{Na}_{2} \mathrm{Ti}_{6} \mathrm{O}_{13}$ is reported to be approximately $0.8 \mathrm{~V}$ with the insertion of $\mathrm{Na}^{+}$into the three dimensional tunnel-type structure [12]. The $\mathrm{Na} / \mathrm{Li}_{2} \mathrm{Ti}_{5} \mathrm{O}_{11}$ cell showed a little higher voltage of $1.2 \mathrm{~V}$ than $0.8 \mathrm{~V}$ on the discharge process which corresponds to the intercalation of $\mathrm{Na}^{+}$and the reduction of $\mathrm{Ti}^{4+}$ to $\mathrm{Ti}^{3+}$ in the layer structured titanate. The first charge and discharge capacities were $120 \mathrm{mAh} / \mathrm{g}$ and $100 \mathrm{mAh} / \mathrm{g}$; the amounts of $\mathrm{Na}^{+}$intercalated and deintercalated were 1.9 and 1.6 of the formula unit, respectively. At 10th cycle, the cell exhibited $60 \%(72 \mathrm{mAh} / \mathrm{g})$ of the first discharge capacity and $70 \%(70 \mathrm{mAh} / \mathrm{g})$ of the first charge capacity.

Figure 5 shows the discharge-charge curves of $\mathrm{Na} / \mathrm{Na}_{2} \mathrm{Ti}_{5} \mathrm{O}_{11}$ cell. The cell voltage decreased from $2.7 \mathrm{~V}$ to $1.4 \mathrm{~V}$ and decreased to $1.2 \mathrm{~V}$. Then it decreased slowly to the cutoff voltage of $0.5 \mathrm{~V}$. The discharge capacity was $120 \mathrm{mAh} / \mathrm{g}$ for the first cycle. The amount of $\mathrm{Na}^{+}$intercalated in this process was 2.1 for the formula unit. The first charge and discharge capacities were $120 \mathrm{mAh} / \mathrm{g}$ and 60 $\mathrm{mAh} / \mathrm{g}$; the amounts of $\mathrm{Na}^{+}$intercalated and deintercalated were 2.1 and 1.0 of the formula unit, respectively. At 10th cycle, the cell exhibited $40 \%(48 \mathrm{mAh} / \mathrm{g})$ of the first discharge capacity and $73 \%(44 \mathrm{mAh} / \mathrm{g})$ of the first charge capacity.

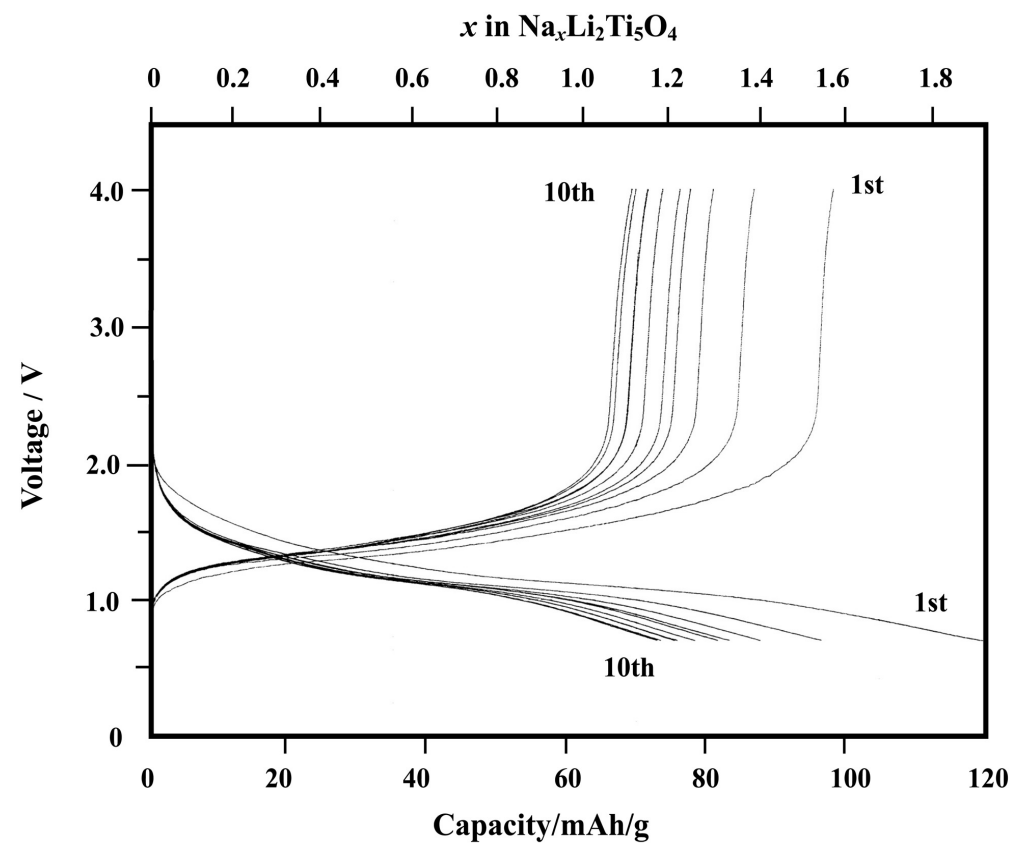

Figure 4. Discharge-charge curves of $\mathrm{Na} / \mathrm{Li}_{2} \mathrm{Ti}_{5} \mathrm{O}_{11}$ cell with $0.10 \mathrm{~mA} / \mathrm{cm}^{2}$. 


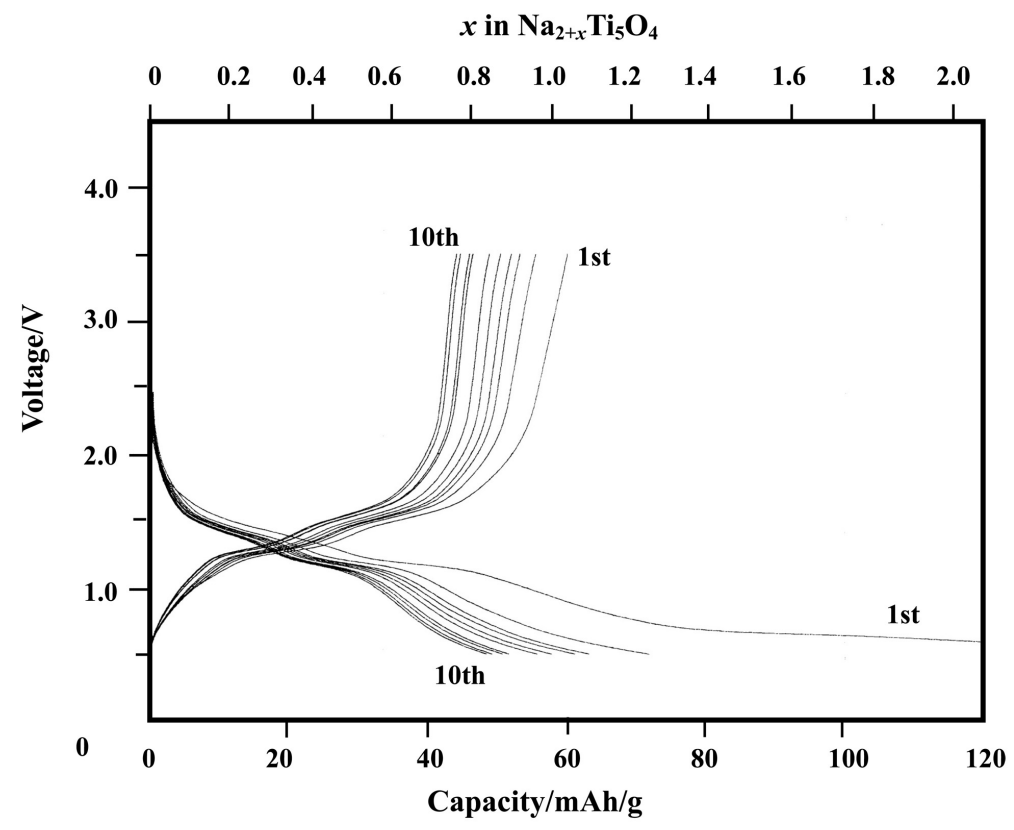

Figure 5. Discharge-charge curves of $\mathrm{Na} / \mathrm{Na}_{2} \mathrm{Ti}_{5} \mathrm{O}_{11}$ cell with $0.10 \mathrm{~mA} / \mathrm{cm}^{2}$.

Figure 6 shows the discharge-charge curves of $\mathrm{Na} / \mathrm{H}_{2} \mathrm{Ti}_{5} \mathrm{O}_{11}$ cell. The cell voltage decreased from $2.7 \mathrm{~V}$ to $0.7 \mathrm{~V}$ and then slowly decreased to the first cutoff voltage of $0.55 \mathrm{~V}$. The discharge capacity was $120 \mathrm{mAh} / \mathrm{g}$ for the first cycle. The amount of $\mathrm{Na}^{+}$intercalated in this process was 1.8 for the formula unit. The first charge and discharge capacities were $120 \mathrm{mAh} / \mathrm{g}$ and $45 \mathrm{mAh} / \mathrm{g}$; the amounts of $\mathrm{Na}^{+}$intercalated and deintercalated were 1.8 and 0.7 of the formula unit, respectively. At 10th cycle, the cell exhibited $28 \%(33 \mathrm{mAh} / \mathrm{g}$ ) of the first discharge capacity and $65 \%(29 \mathrm{mAh} / \mathrm{g})$ of the first charge capacity.

The $\mathrm{Li}^{+}$exchange product showed the best performance in the discharge-charge capacities. The higher performance of $\mathrm{Li}^{+}$exchange titanate than $\mathrm{Na}^{+}$exchange titanate may be attributed to the difference of ionic radius of $\mathrm{Li}^{+}$and $\mathrm{Na}^{+}$. The smaller ion volume of $\mathrm{Li}^{+}$than $\mathrm{Na}^{+}$can provide a lager vacant space for the intercalation of $\mathrm{Na}^{+}$. It is expected that $\mathrm{H}^{+}$exchange titanate has the largest vacant space for the intercalation of $\mathrm{Na}^{+}$among the ion exchange titanates obtained in this study. However, the $\mathrm{H}^{+}$exchange titanate showed the worst performance of the discharge-charge capacities. It is necessary to investigate the structural changes during the discharge-charge processes for further understanding of these cathode materials.

The studies of these titanates for lithium ion batteries are now under way and will be presented elsewhere.

\section{Conclusion}

In this study, we showed for the first time that the layer structure titanates derived from $\mathrm{Cs}_{2} \mathrm{Ti}_{5} \mathrm{O}_{11} \cdot(1+\mathrm{x}) \mathrm{H}_{2} \mathrm{O}$ by ion exchange can be promising candidates for the cathode materials of sodium ion batteries. The initial $\mathrm{Na}^{+}$intercalation-deintercalation capacities of the $\mathrm{Li}_{2} \mathrm{Ti}_{5} \mathrm{O}_{11}$ were $120 \mathrm{mAh} / \mathrm{g}$ and $100 \mathrm{mAh} / \mathrm{g}$; 


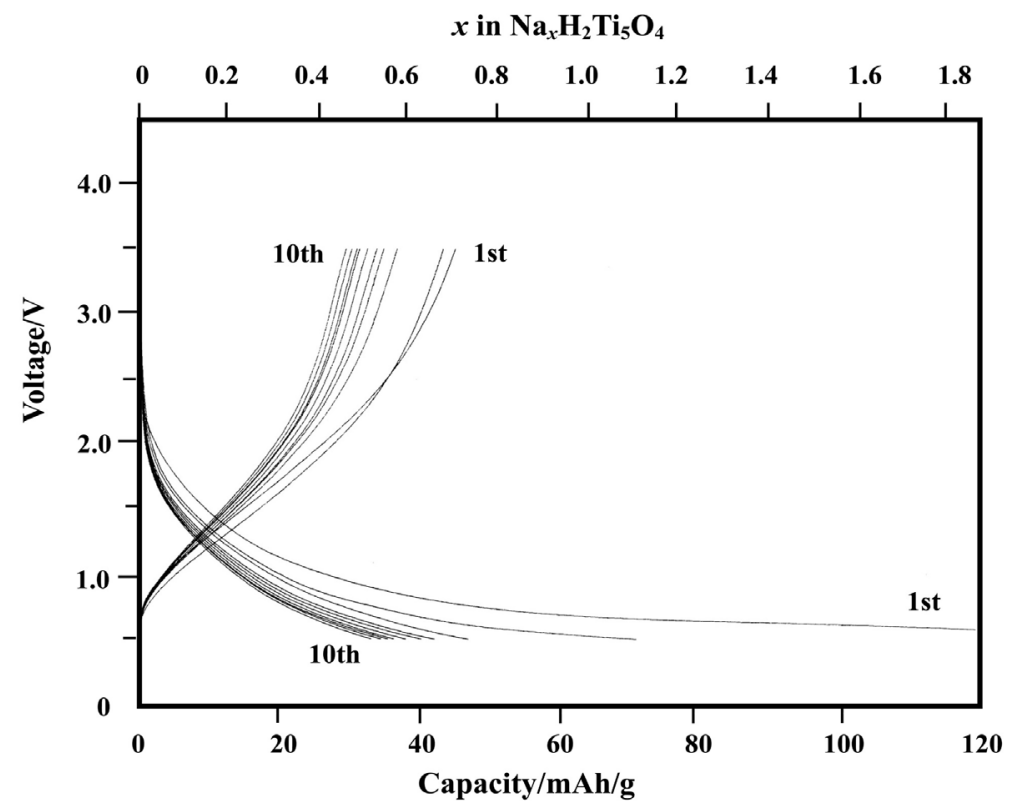

Figure 6. Discharge-charge curves of $\mathrm{Na} / \mathrm{H}_{2} \mathrm{Ti}_{5} \mathrm{O}_{11}$ cell with $0.10 \mathrm{~mA} / \mathrm{cm}^{2}$.

the amounts of $\mathrm{Na}^{+}$intercalated and deintercalated were 1.9 and 1.6 of the formula unit, respectively. The titanates are nontoxic, inexpensive and environmentally benign.

\section{References}

[1] Ohashi, M. (1998) Preparation and Lithium Intercalation of Layer Structured Titanate $\mathrm{Cs}_{\mathrm{x}} \mathrm{Ti}_{2-\mathrm{x} / 4} \mathrm{O}_{4}(\mathrm{x}=0.68)$. Molecular Crystals and Liquid Crystals, 311, 51. https://doi.org/10.1080/10587259808042365

[2] Ohashi, M. (2000) Ion Exchange of Layer Structured Titanate $\mathrm{Cs}_{\mathrm{x}} \mathrm{Ti}_{2-\mathrm{x} / 4} \mathrm{O}_{4}(\mathrm{x}=0.68)$ and Ionic Conductivity of the Products. Molecular Crystals and Liquid Crystals, 341, 265. https://doi.org/10.1080/10587250008026151

[3] Ohashi, M. (2002) Preparation of Layer Structured Crystal $\mathrm{Cs}_{\mathrm{x}} \mathrm{Ti}_{2-\mathrm{x}} \mathrm{Mn}_{\mathrm{x}} \mathrm{O}_{4}(\mathrm{x}=0.70)$ and Application to Cathode for Rechargeable Lithium Battery. Key Engineering Materials, 216, 119. https://doi.org/10.4028/www.scientific.net/KEM.216.119

[4] Ohashi, M. (2002) Preparation of Layer-Structured Crystal $\mathrm{K}_{\mathrm{x}} \mathrm{Ti}_{2-\mathrm{x}} \mathrm{Mn}_{\mathrm{x}} \mathrm{O}_{4}(\mathrm{x}=0.75)$ and Application as Cathode Material in Rechargeable Lithium Battery. Key Engineering Materials, 218-229, 289.

[5] Ohashi, M. (2004) Preparation and Ion Exchange of Layer Structured Cesium Chromium Titanate $\mathrm{Cs}_{\mathrm{x}} \mathrm{Ti}_{2-\mathrm{x}} \mathrm{Cr}_{\mathrm{x}} \mathrm{O}_{4}(\mathrm{x}=0.70)$. Journal of the Ceramic Society of Japan, Supplement, 112-1, S114.

[6] Ohashi, M. (2004) Preparation of Layer Structured Titanate $\mathrm{Cs}_{\mathrm{x}} \mathrm{Ti}_{2-\mathrm{x}} \mathrm{Fe}_{\mathrm{x}} \mathrm{O}_{4}(\mathrm{x}=0.70)$ and Application as Cathode Material in Rechargeable Lithium Battery. Solid State Ionics, 172, 31. https://doi.org/10.1016/j.ssi.2004.01.035

[7] Ohashi, M. (2009) Ion Exchange of Layer Structured Crystal $\mathrm{K}_{\mathrm{x}} \mathrm{Ti}_{2-\mathrm{x}} \mathrm{Fe}_{\mathrm{x}} \mathrm{O}_{4}(\mathrm{x}=0.80)$ and Its Application as Cathode Material in a Rechargeable Lithium Battery. Key Engineering Materials, 388, 97.

https://doi.org/10.4028/www.scientific.net/KEM.388.97

[8] Ohashi, M. (2010) Ion Exchange Layer Structured Niobate $\mathrm{Cs}_{4} \mathrm{Nb}_{6} \mathrm{O}_{17} \cdot 3 \mathrm{H}_{2} \mathrm{O}$ and Its 
Application as Cathode Material in a Rechargeable Lithium Battery. Key Engineering Materials, 445, 65. https://doi.org/10.4028/www.scientific.net/KEM.445.65

[9] Kwiatkowska, J., Grey, I.E., Madsem, I.C. and Bursill, L.A. (1987) An X-Ray and Neutron Diffraction Study of $\mathrm{Cs}_{2} \mathrm{Ti}_{5} \mathrm{O}_{11}$ and $\mathrm{Cs}_{2} \mathrm{Ti}_{5} \mathrm{O}_{11} \cdot \mathrm{X}_{2} \mathrm{O}, \mathrm{X}=\mathrm{H}, \mathrm{D}$. Acta Crystallographica, B43, 258-265. https://doi.org/10.1107/S010876818709791X

[10] Grey, I.E., Madsen, I.C., Watts, A., Bursill, L.A. and Kwiatkowska, J. (1985) New Cesium Titanate Layer Structures. Journal of Solid State Chemistry, 58, 350. https://doi.org/10.1016/0022-4596(85)90217-8

[11] Sasaki, T., Komatsu, Y. and Fujiki, Y. (1992) Protonated Pentatitanate: Preparation, Characterizations, and Cation Intercalation. Chemistry of Materials, 4, 894-899. https://doi.org/10.1021/cm00022a027

[12] Rudola, A., Saravanan, K., Devaraj, S., Gong, H. and Balaya, P. (2013) $\mathrm{Na}_{2} \mathrm{Ti}_{6} \mathrm{O}_{13}$ : A Potential Anode for Grid-Storage Sodium-Ion Batteries. Chemical Communication, 49, 7451. https://doi.org/10.1039/c3cc44381g 